\title{
5 The Historical Roots of Indonesia's New Order: Beyond the Colonial Comparison
}

\author{
ROBERT CRIBB
}

In the middle of the 1960s, Indonesian politics took an apparently profound turn. The personalised, charismatic rule of the country's first president, Sukarno, gave way to the dour, sometimes almost anonymous, administrative style of a new president, Soeharto, a general and former head of the army's strategic reserve. Indonesia's strident leftist engagement with world affairs gave way to a quiet alignment with the West. Within Indonesia, the permitted space for public politics contracted sharply: whereas shrill ideological assertion had been the motor of politics under Sukarno's Guided Democracy, the regime of Soeharto relegated explicit ideology and demonstrative politics to the margins of public life. And economic decay gave way to a sustained programme of development that raised Indonesia from the ranks of the world's poorest nations to become an incipient Asian tiger.

Soeharto called his regime the New Order, and it was indeed a sharp contrast with the 'Old Order', a term which came to encompass both the Guided Democracy of Sukarno and the seven years of parliamentary democracy which preceded it. But where, if it was indeed new, did the New Order come from? Part of the answer lies, of course, in the broader global developments of the time. Indonesia was one of several repressive developmentalist regimes (Feith 1982a) in the Third World in which authoritarian leaders employed state power and the support of the United States in the name of kick-starting what was meant to be a self-sustaining development process. In this respect, Soeharto's Indonesia resembled the South Korea of Bak Jeonghui (Park Chung Hee), the Philippines of Marcos, and the Iran of Shah Mohammad Reza Pahlavi. As the divergent fates of these cases suggest, however, global circumstances were not the only determining factors at work in the emergence or functioning of these regimes. To understand where they came from, we also need to look at history. But which history? 
In the immediate aftermath of independence (1945) and the Dutch transfer of sovereignty (1949), the dominant assumption amongst scholars of Indonesia had been that Indonesia was embarked on a steep but otherwise straightforward path to modernity (and specifically to liberal democracy). Dutch colonialism, it was said, had set the archipelago on a path to modernity, creating the modern state and giving access to modern ideas, and in doing so it had sown the seeds of its own destruction as Indonesian nationalism arose to claim independence by turning the West's own values and rhetoric of freedom and justice against it. With independence secured, Indonesia's task was 'nation-building', a code term for constructing a civil and political order which resembled those of the western democracies. Already in the mid-1950s, however, the prolific and underrated Dutch-American scholar Justus van der Kroef began to reflect on the persistence of apparently traditional patterns of politics in Indonesia. In an idiosyncratic and rather philosophical article, he identified what he called a 'colonial deviation' in Indonesian history (Kroef 1956). By this coinage, he meant that the colonial era, including its immediate aftermath in the form of the Dutchinspired liberal political order of the early 1950s, could be seen as a departure from the 'natural' pattern of Indonesian politics and that what followed in the broad decolonisation process might be something other than a simple following of the trajectory mapped our earlier by the West. Van der Kroef was writing at a time when the strains in Indonesia's parliamentary system had not yet brought it down and his insight was correspondingly speculative. By the early 1960s, however, the disappearance of the parliamentary order, apparently without significant regret among the forces then dominating the political system in the Indonesian political system, seemed to suggest that some hitherto unrecognised dynamic was at work.

The idea of a colonial and liberal democratic deviation in Indonesian history was cemented into scholarly analysis in 1962, when Harry Benda, reviewing Herbert Feith's Decline of Constitutional Democracy, memorably described Feith as 'presenting us highly sophisticated and persuasive answers to an intrinsically mistaken, or irrelevant, question' (Benda 1964:450). Sukarno's Guided Democracy, Benda suggested, could be seen as a return to indigenous political forms which reflected basic cultural understandings of politics that had survived the colonial era despite the gloss of westernisation. Benda's proposition resonated with a contemporaneous scholarly determination to purge Indonesian history of the idea that the Indian culture which had dominated the archipelago from the 1st century to the 14th had been a consequence of Indian imperial initiative. Citing van Leur's memorable characterisation of foreign influences as a 'thin and flaking glaze', scholars argued that Indonesians had held the initiative and had been highly selective of foreign cultural elements (Leur 
1955:95). Benda's argument thus marked the first of a series of influential works arguing the centrality of the cultural dimension in Indonesian politics (Willner 1966; Dahm 1969; Anderson 1972).

Barely had this line of argument taken off when Sukarno's Guided Democracy came to a violent end in 1965-66 and Soeharto's New Order took its place. Soeharto initially appeared to be returning Indonesia to a modified version of the old liberal trajectory (one in which democracy was temporarily postponed in the name of practical development). Soeharto had been in power for barely half a decade, however, when observers began to notice intriguing resemblances between his rule and that of the colonial order which had come to an end in 1942. The first scholar to develop this argument in print was the Dutch sociologist Jacques van Doorn in a book entitled Orde-opstand-orde [Order, rebellion, order] (1973). Ruth McVey then explored the idea in a paper, 'The Beamtenstaat in Indonesia', written in 1977 but not published till 1982. She suggested that the ruling elites in both the late colonial order and the New Order were culturally alien from the people they ruled, the Dutch because of their obvious foreignness, the New Order elite because of its wealth and cultural assimilation to the West. As aliens, both elites lacked the rhetorical tools to recruit the loyalty of their subjects, and in consequence they both adopted a strategy of political demobilisation. She also suggested, less convincingly, that both elites were driven by a 'gnawing sense of illegitimacy' into an emphasis on superficial legal forms and on the promise of an eventual transition to democracy (McVey 1982:84,87) but in the end she implied, despite her article's title, that differences outweighed similarities.

The scholarly thesis that Soeharto was the heir of the late colonial state achieved its most developed form in an article, 'Old state, new society', published by Ben Anderson in 1983. Anderson characterised the New Order as a 'resurrection of the state and its triumph vis-à-vis society and nation' (p.487). The resurrected state was that which the Dutch East Indies Company had founded in the early 17th century and which had expanded dramatically over the subsequent centuries, encompassing most of the archipelago and penetrating with increasing force into the daily life of its inhabitants. The central characteristic of this state, as portrayed by Anderson, was its self-serving purpose: it had no responsibility to its society and the main purpose of its revenue collecting activities was to fund itself as a gigantic consumer of Indonesian wealth. These resources in turn gave it the power and the confidence to impose its will on reluctant parts of the archipelago such as Aceh. The Republic of Indonesia which declared independence in 1945 claimed to be the successor state of the Netherlands Indies in international law, but, according to Anderson, it differed from the colonial state in key respects: its leaders were not from the colonial establishment, they based their claim to power on an idea of representing the 
Indonesian people and for two decades the state presided over a society out of control. The New Order, by contrast, with its managed elections and its vast sources of funds from resource rents and foreign aid, independent thus of a public tax base and consequent public responsibility, and with its brutal adventure in East Timor, replicated central features of the colonial state. In Anderson's analysis, moreover, Soeharto as an individual played a central role in this replication because his career had begun in the security apparatus of the colonial state. In Anderson's view, Soeharto consciously constructed the New Order as a new incarnation of the colonial state, asserting its power over society and its access to resources for its own officials.

Anderson's development of Van Doorn's insight has had a persistent, though indefinable, effect on the scholarly interpretation of the New Order. ${ }^{1}$ Pheng Cheah cites Anderson when describing the New Order as 'the genealogical heir of the Dutch colonial state' (2003:255); Anwar cites him approvingly (1994:160); Nordholt's discussion of a 'genealogy of violence' in Indonesia nods respectfully in his direction (2002). Like all provocative insights, however, the equation of New Order and colonial era runs the risk of being carried beyond the level of insight into the realm of truism. It may be time, therefore, to put insight into perspective by identifying a few key areas in which the New Order and the colonial signally fail to resemble each other. In fact, in important respects, the New Order constituted the apotheosis of reaction against the colonial order.

\section{Unity and diversity}

Perhaps the single most striking difference between the New Order and the colonial era lay in the New Order's emphasis on unity, uniformity and conformity. By contrast, the colonial era was characterised by a thoroughgoing fragmentation of society, culture and politics.

It is a cliché of colonialism in most of the world that it applied a technique of divide and rule. The case that colonialism in the Indonesian archipelago divided a previously united society would be hard to make, but there is no doubt that the Dutch systematically preserved difference within their political order. This strategy of preserving difference emerged initially out of purely pragmatic calculations. The Dutch East Indies Company, and after it the Netherlands colonial regime, had as their main aims (until 1900) the extraction of profit from the Indonesian archipelago. They had no sense of an obligation to provide services to their colonial subjects and, as a matter of frugality, they aimed to leave the indigenous peoples of the archipelago as far as possible under

1 As of 24 February 2008, it counted 30 citations in the ISI Web of Knowledge, 34 in Google Scholar and 140 in Google Books. 
their indigenous rulers. As time passed, frugal practice turned into colonial doctrine: the Dutch increasingly believed as a matter of principle that colonial peoples should be ruled according to their own cultural norms. Given that those norms existed in a vast range of forms, the colonial authorities presided over a baroquely complicated administrative system. The colonial order distinguished between directly and indirectly ruled territories, the latter numbering some 282 at the end of the colonial era and covering about half the area of the colony (though much less than half the population). Laid over this administrative order was a legal system bifurcated between government and Native law, and bifurcated again, but not along the same lines, between government and Native courts. Through the system of customary law (adatrecht), the Dutch recognised thousands of local practices, different from district to district, as having the force of law, especially in matters to do with land use, marriage and inheritance. Laid over the system again was an immensely complex system of racial classification. Although there was a crude classification of the population of the archipelago into three categories Europeans, Natives and Foreign Orientals (Fasseur 1994), this classification was made less salient by the existence of dozens of subclassifications within each category. Japanese (classified as European from 1899) were not treated the same as Germans; Chinese were not treated the same as Indians or Arabs. The category of 'Native' (Inlander) counted in some circumstances, but in other circumstances it was less significant than the fact that one was Javanese or from, say, Banyumas.

Even if the Dutch did not consciously intend to keep the inhabitants of the archipelago disunited as a device for sustaining colonial rule, they employed the diversity argument with alacrity as soon as a nationalist challenge emerged in the early 20th century. The Leitmotiv of the Dutch defence of colonial rule in the final decades before the Second World War was an emphasis on the uneven development of Indonesians. This proposition allowed them to claim that continued colonial rule was necessary to protect the weaker elements of Indonesian society from the stronger (an argument which carried on through the war years into the strategy of creating a federal, semi-independent Indonesia with the different regions under varying degrees of colonial tutelage; this argument also ultimately underpinned in the separation of West New Guinea from Indonesia in 1949).

For Indonesian nationalists, in consequence, refuting the Dutch assertion of diversity and creating their own basis for unity was an obsession. Nationalist leaders routinely observed that the overwhelming numbers of Indonesians would give them a decisive advantage if only they could achieve true persatuan (unity), rather than mere association, mocked by Hatta as persatean (being like unrelated pieces of meat skewered on a bamboo stick) (Legge 1981:157). The Pancasila took form as an encapsulation of Sukarno's conviction that Indonesian 
identity was underpinned by belief in a set of noble principles, not just by shared hostility to colonialism. The Dutch strategy during the Indonesian revolution of constructing a federal state as a pliant alternative to the nationalist Republic and their separation of West New Guinea from Indonesia at the time of the transfer of sovereignty in 1949 only fed this obsession, so that two or three generations of nationalists grew up believing in national unity as a first principle and seeing secession in any assertion of local identity.

The origins of the New Order's obsession with unity (redoubled as persatuan dan kesatuan) lay clearly in this nationalist reaction to the diversity which underpinned the colonial regime, even if it was exacerbated by a somewhat tendentious misreading of the rebellions of the 1950s as separatist. ${ }^{2}$ The Soeharto regime banned locally based parties, starved local languages of state support, herded local identities into a straightjacket of tropes typified by the 'Beautiful Indonesia in Miniature' (Taman Mini) theme park in which the vast cultural diversity of the archipelago was reduced to a single standard for each province, most of the standards being nudged in style towards a single hybrid Malayo-Javanese archetype. A single, coordinated education system, sustained encouragement for population movement as a way of blending the peoples of the archipelago, and the heaviest of military hands set against real and presumed secessionists, all these were implicit in the old nationalist slogan that identified an Indonesia stretching 'from Sabang to Merauke'. It was an obsession with the essential unity and uniformity of the archipelago that ran diametrically against the rich cultural profusion of the colonial era.

\section{Meritocracy}

Soeharto has been gone from power for more than ten years now, but it is still discomforting to say it: the New Order was a meritocracy, or at least it was a meritocracy if one takes a flexible enough view of merit. In this respect, too, the Soeharto regime was utterly unlike the colonial order.

The horror stories that Indonesians tell each other about Dutch colonialism focus on brutal military operations, from genocide in the Banda islands in 1621 (Hanna 1978) to the bloody conquest of Aceh between 1870 and 1900 (Veer 1980), and on economic exploitation, from the callous treatment of labourers in the construction of the Great Post Road along the island of Java in 1808 (Nas and Pratiwo 2002) to the tormenting of workers on the tobacco plantation of

2 The major revolts of the 1950s - the Darul Islam uprising, the Madiun affair, and the PRRI and Permesta rebellions, as well as smaller events such as the APRA and Andi Aziz affairs - were all directed as national politics, not at the breakup of Indonesia. The only revolt which aimed at secession was that of the Republic of the South Moluccas in the early 1950s. 
Sumatra in the late 19th century (Breman 1989). These barbarities, however, were concentrated in a relatively small number of regions of the archipelago and took place during relatively short periods of time. What almost all Indonesians experienced under the colonial order, however, was a fundamental constriction of opportunity.

This constriction operated in several ways. Perhaps most important of all was the pervasive presence of aristocracy in the colonial administrative structure. Indigenous aristocracies played a key role in the colonial order, because the Dutch believed that they possessed traditional authority over the mass of the people and were therefore a bulwark of political stability. As we know from the research of Sutherland (1979), the aristocracies were not simply preserved but enhanced. Whereas in the pre-colonial period there had been a great deal of fluidity in aristocratic status, so that able commoners could rise into the elite and incapable descendants could disappear from it, the colonial system fossilised the social order as it was at the time of the imposition of Dutch rule. Aristocrats were not only affirmed, but were encouraged to take upon themselves the trappings of minor royalty, all for the sake of making a regal impression on the lower classes. This situation applied not just in the indirectly ruled regions but in regions that were nominally directly ruled. Recruitment to the indigenous administrative corps in Java, the Native Administration (Inlands Bestuur), was determined by birth, with the most senior Native post, the district head (bupati), restricted to members of the traditional Javanese elite (priyayi) aristocracy.

The entrenchment of aristocracy meant a serious restriction of social mobility through the administration. Whereas social hierarchies in most pre-colonial states in the archipelago were remarkably fluid, in the colonial era it ceased to be possible to recruit talented individuals from the lower classes into the indigenous ruling elite, because inferior origin made them ineligible. It was also impossible to recruit Indonesians into the European administrative corps (in contrast with the Indian Civil Service of British India, for instance), not only because of European racism but because the system could not countenance a Native commoner rising to a position where he would have authority over Native aristocrats.

Alongside this class-based restriction were the better known obstacles to advancement created directly by race. Although overt racial discrimination, in the form of segregated facilities, was almost unknown in the colonial Indies, lack of formal education and lack of the necessary class connections effectively excluded Indonesians from managerial positions in most private firms and in the specialist technical sections of the colonial administration where lack of aristocratic status was not an issue. The huge offence that the colonial system committed against all its Native subjects was to close off the main paths to social mobility in a society that yearned for advancement. 
The nationalist movement, by contrast, was a consistent enemy of ascriptive privilege. Not everyone went as far as Tjipto Mangoenkoesoemo who called for the Javanese language to be 'killed' because its system of levels of address made it inseparable from aristocratic privilege. But most nationalists agreed that reforming access to government positions should be a central element in their agenda. At the outbreak of the national revolution in 1945, there was a series of social revolutions against aristocracies along the length of Java and Sumatra, in which discontented subjects and rival elites took advantage of the post-war power vacuum to sweep away aristocratic incumbents, sometimes simply consigning them to powerless citizenship, sometimes killing them (Lucas 1991). From a social point of view, too, the new nationalist elite was remarkable for its diverse social origins. The new president, Sukarno, had trained as an architect, his deputy, Mohammad Hatta as an economist. The army commander was a former teacher, the governor of South Sumatra had been a star in light romantic films, the head of the military academy had been a dentist. The barriers erected by the colonial system were breached and the cohort of hungry, capable nationalists flooded into governing positions.

Soeharto was part of the same generation. A village boy, possibly illegitimate, he would have had little hope for a glittering career under the Dutch. In the fluid politics of independent Indonesia, however, he made the most of his opportunities and rose to a position from which, when circumstances suddenly favoured him, he could seize power. Soeharto's presidency was a confirmation of the fact that in the new Indonesia anyone could become president. And the New Order he constructed was precisely in the image of the nationalist movement. Although he made brief use of the Sultan of Yogyakarta, Hamengku Buwono IX, as vice-president, and although he pandered to his wife's connections with the minor princely Mangkunegaran family, the people he surrounded himself with were newcomers - the ruthless, the clever, the lucky, and the opportunist. Soeharto's technique, too, of circulating subordinates through the political system, promoting some, discarding others, catapaulting a select few into new and unexpected posts was correctly interpreted at the time as a cunning system of control which centred political prerogative in the hands of an inscrutable president. But it was also a highly effective system of social mobility; no one was disqualified from power by lack of social rank as had been the case in the colonial era. Disqualification came rather from lack of ability, lack of willingness to do the president's work and, in the closing years of the New Order, lack of obsequiousness. If there were times when Soeharto's court seemed to resemble a zoo, it was a convincing sign that no social standing was needed to make the grade in New Order Indonesia as long as one had the right abilities. Here, too, the New Order's preoccupations were diametrically opposed to the ascriptive obsessions of the colonial order. 


\section{Propaganda}

The New Order was brutal towards those whom it saw as threats. It was callous towards those it needed to use, or whose living spaces it needed to confiscate, for the sake of development. But many Indonesians benefited from the greater social order that the New Order provided and from the pervasive programmes for economic development and social improvement. In one respect, however, the New Order touched the whole of Indonesian society in a way that was as negative as the pervasive lack of social mobility that characterised the colonial system. This respect was propaganda, which infused the New Order in a way that no-one could ignore and which poisoned public life. In the colonial era, by contrast, propaganda played almost no role at all in upholding Dutch rule.

Although the term propaganda is sometimes used to describe any kind of display which intentionally upholds or undermines a political order, the term is better treated more narrowly as referring to a set of messages designed to influence public opinion on a specific topic. The Dutch metropolitan and colonial governments had become aware of the value of propaganda in influencing global public opinion early in the 20th century. From about the beginning of the twentieth century, there was talk in the international community of redistributing colonies to emerging powers such as Germany, the United States and Japan, so that they could have a hand in the task of colonial development. Netherlands was small and weak at the time, and the Dutch metropolitan and colonial governments had been anxious that they might lose parts, or even all, of the colony. This fear prompted a small-scale publicity campaign to inform the world of what the Dutch saw as the good work they were carrying out in the Indies.

But in the direction of the Natives there was no such effort. The reason for this was that the colonial order did not rest to any significant degree on the active consent or direct mobilisation of its indigenous subjects. As we have seen, the lynchpin of colonial rule was aristocratic authority. Although this authority might require reinforcement by means of ceremony and pageant, it was hardly amenable to modern propaganda. Nor was the racial hierarchy of colonial society an attribute that lent itself to being 'sold' by propaganda means. To the extent that the Dutch were interested in the motivations of individual Indonesians, the debate which ran through Dutch colonial policy from at least the middle of the 19 th century was whether Indonesians could be lured into activity by economic incentive or whether their attitude to the world was governed by a culturally determined sense of social obligation. The idea that propaganda might create a sense of commitment to the colonial order was simply not present. 
In fact the Dutch did believe in propaganda, but only as a tool employed by their enemies. From the first emergence of nationalist objections to Dutch rule, the colonial authorities suspected that naïve, good-hearted Natives were being led astray by Islamic and/or Communist propaganda. Censorship of political materials and the exiling of 'agitators' was thus a key part of the colonial strategy to maintain power (Poeze 1982-1994). But the Dutch themselves never ventured into any form of serious counter-propaganda.

Serious political propaganda, rather, was introduced to Indonesia by the Japanese occupation. The Japanese military authorities were at best sceptical about power of traditional rulers to mobilise Indonesians for the war effort, and they had no time to devise systems of economic incentive. Instead they immediately established a Propaganda Section (Sendenbu) with the task of persuading Indonesians to back occupation policies and participate enthusiastically in the war effort (Kurasawa 1987). There was no precedent in Indonesian history for such a concerted effort to change public opinion. Although in some respects the Japanese simply released pent-up resentment of colonial rule that pre-dated the Occupation, the propaganda of the Japanese period had a profound awakening effect on Indonesian political consciousness. It was a lesson obvious to most nationalist leaders, and the subsequent war of independence from 1945 to 1949 was conducted not only in the battlefield and at the negotiating table but also in the form of a propaganda struggle for the hearts and minds of Indonesians.

As well as comprehending the power of propaganda to shape attitudes, the Indonesian nationalists learnt a subsidiary lesson about propaganda from the Japanese. This lesson was that, in its attention to public opinion, propaganda is a kind of bastard child of democracy. Propaganda does not mean accountability or even consultation, but it shows an underlying respect for the masses by regarding their opinions as important. The Japanese eagerness to win public support contrasted sharply with the transparent disappointment of many Dutch with their colonial subjects. The comment of an unnamed colonial official in the 1930s - 'As soon as we withdraw our hands, everything sinks back into the marsh' (Furnivall 1948:229) - is reminiscent of nothing so much as the reported comment of the Russian Tsar a few decades earlier; offered the suggestion that his people might have lost confidence in him, he responded to the effect: 'Surely the question is whether I have confidence in them $?^{\prime 3}$

Soeharto came to power in 1965-66 after an era of intense propaganda in Indonesian public life, and his initial reaction was to sweep propaganda, and all manifestations of politics, into the dustbin of history. After the Malari riots of 1974, which appeared at the time to be a serious popular challenge to his regime, he changed direction and turned propaganda into a central element of

3 For an allusion to this (perhaps apocryphal) comment, see Gerhardie, 1939, p.450. 
his political enterprise. By means of the P4 programme ${ }^{4}$, he made ideological indoctrination a pervasive element in the national education system (Morfit 1981). This attention to propaganda marked Soeharto out as very different from the earlier colonial rulers, but in his use of propaganda he also differed sharply from his immediate nationalist forebears. Despite the huge effort that was put into inculcating the Pancasila into generations of school and university students, as well as public servants, military personnel and anyone else who came within reach, his aim was not to change people's minds by locking on to their emotions as the Japanese and Sukarno had sought to do, nor even to create a simulacrum of democratic consultation. Rather, his propaganda can be characterised by the term 'white noise', which was coined to describe featureless noise generated for the purpose of masking other sounds. Like white noise, the Pancasila was not meant to be noticed and acted upon (it lacked not just the intellectual but also the emotional content to become a serious guide to action). Rather it was intended to fill with nothingness the intellectual space that might otherwise have been contested by real political thinking. This empty character of the New Order's Pancasila is the explanation for the sudden disappearance after Soeharto resigned of what purported to be national ideology inculcated into the Indonesian people in millions of hours' instruction over more than two decades.

\section{Urgency}

Whereas the effort that the New Order put into propaganda was essentially directionless, its commitment to economic development was consistently sustained and purposeful. Although Indonesia is reputed to be a place of 'rubber time' (jam karet), where deadlines drift on the margins of life without ever being met, there was nothing casual about the New Order's commitment to the development effort. The most important positive characteristic of the Soeharto era, and the feature which lifts it above other Third World authoritarian regimes whose record was marred by brutality and corruption, was its sustained programme of development whose benefits reached far beyond the immediate interests of the ruling elite. No official document title sums up the New Order's intentions better than Ali Moertopo's Basic thoughts on the acceleration and modernization of 25 years' development (1973). Soeharto and those about him were aware that Indonesia was running a race. The dismal economic legacy of Sukarno meant that it started the race from the back of the field, but the New Order's managers were convinced that astute planning and implementation would enable them to move clear of the basket cases, plough past the middle of the field and follow eventually in the footsteps of Japan, South Korea and

4 Pedoman Penghayatan dan Pengamalan Pancasila, Guide to the Realisation and Implementation of Pancasila. 
Taiwan. These managers were acutely aware that every delay meant prolonging Indonesia's sojourn amongst the less developed countries and prolonging hardship for the Indonesian people. They were driven by a sense of purpose and urgency.

The development strategy which Soeharto and his lieutenants implemented in fact had a significant resemblance to the so-called Ethical Policy of the Dutch colonial government in Indonesia in the early 20th century. This policy, a remarkable reversal of the exploitative policies of the 19th century and earlier, was the world's first sustained attempt to devise a set of policies to deliver economic development in the tropics. The programme was, by most standards, a failure, partly because of its experimental character, partly because funds were too limited to follow through the policy's ambitious aims, and partly because the Dutch were too quickly disappointed by the results (Cribb 1993). By the 1930s, economic development strategies had largely disappeared from the colonial political agenda, and when they reappeared in Indonesia in the late 1960s, they came from thinkers in other parts of the world. In that respect the New Order was no more the direct descendant of the Dutch colonial order than were any of the developing countries which applied the models recommended by Rostow and others.

There were two key differences, moreover, between the Dutch and the New Order in their development policies. First, the Dutch were not significantly driven by any sense of urgency. The initial impetus for the Ethical Policy was a sense of moral obligation to the Indies, a debt of honour incurred by means of exploitation during earlier centuries, which should be expunged by paying attention for the first time to the welfare of the indigenous people of the archipelago. Misgivings over the Policy, rather, were more than anything else based upon a fear that it had moved too fast, creating a discontented 'intellectual proletariat' which was ripe for seduction by subversive outside ideas. Second, the Ethical Policy was relatively short-lived. It was slower to start than the New Order's development programme and came to a more rapid end. By the 1920s, the Ethical Policy had begun to give way to that last justification of foreign rule, mentioned earlier, that only foreigners could protect the weaker sections of Indonesian society from the stronger. This justification was completely without a sense of urgency. It implied that Dutch rule would always be necessary to keep the peace. During his last years, it is true, Soeharto also showed a loss of policy vigour, but he never abandoned the development paradigm, and there was a gathering air of impatience in Indonesian politics as younger people waited for the old man to depart (see Cribb 1990:24; Crouch 1992:61-62; Schwarz 1994). 


\section{Conclusion: dualism and historical roots}

The past works powerfully in the present. Institutional structures and habits of mind that were shaped in earlier periods can live on long after the forces that brought them into being have ceased to function. The persistence of the past is often a critical source of social resilience and cultural capital that sustains societies through difficult times. It can also work, however, as a straightjacket that restricts opportunities to shape the future. For this reason, most political programmes involve sustaining some elements from the past while rejecting others. Indonesia's recent history has been marked by unusually strong reactive swings against the immediate past. Supporters of the present reformasi era insist that it is a radical departure from the New Order, pointing to such dramatic reforms as decentralisation (with its far-reaching administrative, political and cultural consequences), democratisation, the letting go of East Timor, the removal of legal restrictions on Chinese Indonesians, and serious attempts to combat corruption. The New Order in turn painted itself as antithetical to Sukarno's 'Old' order, Sukarno sharply contrasted his Guided Democracy with the 'free-fight liberalism' of the parliamentary era, the Republic of Indonesia presented itself as the polar alternative to Dutch colonialism; even the Ethical Policy was presented as a fundamental reversal of the exploitative colonial policies of the 19th century.

This sense of repeated elemental changes of direction in Indonesian leads easily to a dualistic fallacy, as if Indonesia has simply flipped, time and again, between two basic options. Dualism is a powerful philosophical device, but it is crude history. Like other political orders in the Indonesian archipelago, the New Order was both a reaction to and a continuation of the political forms that preceded it. We can find in its complex structure elements that perpetuated forms and assumptions drawn from the Guided Democracy, from liberal nationalism, from the Japanese occupation, from the Dutch colonial era and from pre-colonial polities. At the same time it was a reaction against each of the eras that preceded it. To assert, on the basis of just a few similarities, that the New Order was in essence a resurrection of the colonial era is polemic rather than serious analysis. The colonial era contributed both institutions and assumptions to independent Indonesia, but it also provided a crucial antithetical model against which the New Order defined its vision for the archipelago. 